Slavov, G. T., S. P. DiFazio and S. H. Strauss (2004): Gene flow in forest trees: gene migration patterns and landscape modeling of transgene dispersal in hybrid poplar, pp. 89-106. In: Introgression from Genetically Modified Plants into Wild Relatives, edited by H.C.M. DEN NiJs, D. BARTSCH and J. SweEt. CAB Int., Wallingford UK.

Smith, D. and M. Devey (1994): Occurrence and inheritance of microsatellites in Pinus radiata. Genome. 37: 977-983.

SUlTAN, S. E (1987): Evolutionary implications of phenotypic plasticity in plants. Evolutionary Biology. 21: 127-178.

SzmidT, A. and O. Muona (1985): Genetic effects on Scots pine (Pinus sylvestris L.) domestication, pp. 241-252. In: Population genetics in forestry, edited by H. R. GREGORIOUS. Springer, Berlin, Heidelberg, New York, Tokyo.

Vogl, C., A. KarhU, G. Moran and O. SAVOlainen (2002): High resolution analysis of mating systems: inbreeding in natural populations of Pinus radiata. J. Evol. Biol. 15 (3): 433-439.
WANG, J. (2005): Estimation of effective population sizes from data on genetic markers. Phil. Trans. R. Soc. B. 360: 1395-1409.

White, T. L., W. T. Adams and D. B. Neale (2007): Forest Genetics. Oxfordshire, United Kingdom. CABI Publishing.

Wu, J., K.V. KRUTOvskil and S. H. Strauss (1999): Nuclear DNA diversity, population differentiation, and phylogenetic relationship in the Californian closed-cone pines based on RAPD and allozyme markers. Genome. 42: 893-908.

Wu, H. X., K. Eldridge, C. Matheson, M. Powell, T. McRAe, T. Butcher and I. Johnson (2007): Achievements in forest tree improvement in Australia and New Zealand 8. Successful introduction and breeding of radiata pine in Australia. Aust. For. 70 (4): 215-225.

YEH, F. C. and T. BOYLE (1999): POPGENE VERSION 1.31 Microsoft Window-based Freeware for Population Genetic Analysis. University of Alberta. Canada.

\title{
Flowering phenology and germination ability of pollens for Acacia mangium and A. auriculiformis
}

\author{
By K. Kato ${ }^{1), *)}$, S. YAmaguchi ${ }^{2)}$, O. Chigira ${ }^{3)}$ and N. Osaka ${ }^{1)}$
}

(Received $2^{\text {nd }}$ February 2012)

\begin{abstract}
A four-year investigation was conducted on the flowering phenology and germination ability of pollens from $A$. mangium and $A$. auriculiformis ramets to determine whether the flowering phenology and germination ability of pollens differed among clones or seed sources. The number of $A$. mangium and $A$. auriculiformis clones used was 19 and 23 , collected from 17 and 8 seed sources, respectively. The flowering of each ramet was visually observed every three or four days for three seasons, with one season being from April to the following March, and the germination ability of pollens collected from the flowers was investigated at 1 day, 6 months, and 12 months after being stored at $-18^{\circ} \mathrm{C}$. The mean percentage of flowering per clone which was calculated by dividing the number of flowering ramets by the num-

\footnotetext{
${ }^{1)}$ Iriomote Tropical Technical Garden, Forest Tree Breeding Center, Forestry and Forest Products Research Institute, Komi, Taketomi, Yaeyama 907-1432, Japan.

2) Present address: Tohoku Breeding Office, Forest Tree Breeding Center, Forestry and Forest Products Research Institute, Osaki, Takizawa 020-0173, Japan.

$\left.{ }^{3}\right)$ Present address: Forest Tree Breeding Center, Forestry and Forest Products Research Institute, Juo, Hitachi 319-1301, Japan.

*) Correspondig author: KAZUTAKA KATO. Tel: +81-0980-85-5007, Fax: +81-0980-85-5035. E-Mail: katoka@affrc.go.jp
}

ber of ramets used was low on $A$. mangium for each season, whereas it was more than $60 \%$ on $A$. auriculiformis for each season, with no significant variations among the seasons. The flowering initiation and flowering period also showed non-significant variations or differences among the seasons and among most of the clones within the seed sources. On the other hand, the percentage of flowering per clone, the flowering initiation, and the flowering period on A. auriculiformis showed significant variations and differences among the seed sources although those were similar on some seed sources. On both tree species, the germination rate of pollens per clone showed significant variations among clones, regardless of the seasons and number of days stored, and also among clones within seed sources for about half the cases. These results suggest that the flowering phenology is in some degree determined by a genetic factor such as the seed source, whereas the germination ability of pollens is mainly determined by a genetic factor in each clone.

Key words: Acacia hybrid, Acacia mangium, Acacia auriculiformis, Artificial pollination, Flowering phenology, Pollen germination.

\section{Introduction}

Acacia hybrids formed by crossing A. auriculiformis and $A$. mangium were first discovered in the field in 
Sabah, Malaysia during the 1970s (THAM, 1976; PeDLEY, 1978). Because their morphological traits, such as growth rate, stem straightness, wood density, and resistance to pests and diseases, show superior silvicultural characteristics over both parents (KHA, 1996), these hybrids have been subjected to mass propagation by rooted cutting. Artificial hybridization has already been carried out (SEDGLEY et al., 1991a) and the wood properties have been discussed (KIM et al., 2009). In the future, it is expected that superior hybrids will be established by conducting numerous artificial pollinations with many combinations of parent trees.

However, because the flowering period of each spike is only 1 or 2 days (SEDGLEY et al., 1992), and pollination is limited to the early morning hours (OGAwA et al., 2008), the period available for artificial pollination for each flower is very short. SEDGLEY et al. (1991a) also reported that the average time taken for a single pollination to pollinate one spike of $A$. auriculiformis was more than 10 minutes, suggesting that the number of available artificial pollinations conducted per day is extremely low. Therefore, it is important to design an accurate annual plan for conducting systematic artificial pollination between parents and thus requires a thorough understanding of the flowering phenology of each parent tree beforehand. Although there have been a few studies investigating the flowering phenology of A. Mangium and A. auriculiformis on forest stands (JosUE, 1992; SEDGLEY et al., 1991b), no studies have been conducted to detect the flowering phenology of each tree.

Generally, the flowering phenology is determined by biotic and abiotic factors (RATHCKE and LACEY, 1985) and great variations of flowering phenology among cultivars or clones have been reported on other tree species (Matthew et al., 2004; Garcia-Mozo et al., 2009). Among the biotic factors, the seed source, i.e. the ecotype, may also be one of the factors influencing flowering phenology within a species (NoRCINI et al., 2001; HARTMAN et al., 2012). A. mangium and A. auriculiformis are distributed from the northern part of Australia to Papua New Guinea (PNG), and the Commonwealth Scientific and Industrial Research Organization (CSIRO) stores a lot of seeds that have been collected from many seed lots (sources) (PINYOPUSARERK et al., 1991); high genetic differentiation between populations has been detected (WICKNESWARI and NoRWATI, 1993). Therefore, if seedlings from many seed sources are planted in the same area, the variations in flowering phenology among them would be apparent. Moreover, if there are any variations in flowering phenology among seed sources, artificial pollination should be conducted more systematically because the annual planning for conducting artificial pollination between the parents can be designed beforehand.

In addition, it is important to comprehend the germination ability of pollens beforehand in order to system- atically conduct artificial pollination, because germination ability is closely related to the success of artificial pollination (SEDGLEY et al., 1993). Although it has been reported that there are clonal variations in the germination ability of pollens for other tree species, such as several rose varieties (VISSER et al., 1977), there have been no precise reports in which variations in the germination ability of pollens among seed sources or clones of A. mangium and A. auriculiformis were detected. If there are any variations, the number of artificial pollinations must be determined based on the germination ability of pollens for each cross combination in order to obtain an adequate number of mature seeds.

Furthermore, it has been reported that the flowering phenology between $A$. mangium and A. auriculiformis (Josue, 1992; SEDGLEY et al., 1991b) is not synchronous. This suggests that, to conduct artificial pollination, pollens from a tree which comes into flower earlier must be stored until a later period when another tree comes into flower. SEDGLEY et al. (1993) reported that the most successful and convenient method of pollen storage involved vacuum drying followed by storage at $-18^{\circ} \mathrm{C}$. Although YAMAGUCHI and OGAWA (2008) reported that the germination rate of pollens stored at $-18^{\circ} \mathrm{C}$ remains at a high level even 2 months after collection, they did not detect any variations in the germination rate of pollens among seed sources or clones. Thus, it is important to detect variations in order to systematically conduct artificial pollination.

In this paper, the flowering phenology of $A$. mangium and $A$. auriculiformis was investigated for three seasons using 19 and 23 clones which consisted of 17 and 8 seed sources, respectively. Pollen samples were also collected from flowering spikes and immediately stored at $-18^{\circ} \mathrm{C}$. The germination rate was investigated at 1 day, 6 months, and 12 months following the collection of pollens. We analyzed the variations in the flowering phenology and germination ability of pollens among clones and seed sources, and within seed sources, and discussed the steps for systematically conducting artificial pollination.

\section{Material and Methods}

\section{Study sites and sample trees}

This study was conducted at the Iriomote Tropical Forest Tree Breeding Technical Garden at the Forest Tree Breeding Center of the Forestry and Forest Products Research Institute in Okinawa Prefecture, southwestern Japan from April 2008 to January 2012. Climate data recorded at the nearest weather station is listed in Table 1, which suggests that this area is subtropical because the annual temperature is mostly around $24^{\circ} \mathrm{C}$. For analyzing variations in the flowering phenology and germination ability of pollens for A. mangium and $A$. auriculiformis, seeds were bought

Table 1. - Monthly mean temperature and mean precipitation at Iriomote island during 2008 April to 2010 March.

\begin{tabular}{|c|c|c|c|c|c|c|c|c|c|c|c|c|c|}
\hline ltems & Jan. & licb. & Mar. & Apr. & May & June & July & Aug. & Scp. & Oct. & Now. & Dee. & Mcan \\
\hline 'l'miperalur "'a & $19.1+0.5$ & $20.0+1.3$ & $21.2+0.3$ & $22.8+0.4$ & $25.5-0.1$ & $28.5+0.1$ & $299-0.3$ & $29.4-0.1$ & $28.6+0.4$ & $26.5+0.2$ & $23.5+0.2$ & $30.6+0.5$ & $24.6+0.1$ \\
\hline Prexipitationl (11шli) & $107+23$ & $147+37$ & $165+66$ & $123+31$ & $173-20$ & $244+34$ & $72+26$ & $200-50$ & $363+180$ & $249+123$ & $303+46$ & $55+23$ & $2097+205$ \\
\hline
\end{tabular}


from CSIRO in 1996. The number of seed sources was 20 for both species. Twenty seeds from each seed source were sowed in the nursery. After 6 months, the surviving seedlings (about 300) were planted in an experimental plot at intervals of $2 \mathrm{~m} \times 2 \mathrm{~m}$, covering 0.3 ha. In 2003 , clones consisting of two ramets were established by layering from $24 \mathrm{~A}$. mangium and $27 \mathrm{~A}$. auriculiformis seedlings that grew smoothly. All layered ramets were potted (black color, diameter of $50 \mathrm{~cm}$, and height of $45 \mathrm{~cm}$ ) at the experimental area at intervals of $3 \mathrm{~m} \times 3 \mathrm{~m}$, covering 0.1 ha. As of 2008 , however, some of the layered ramets were dead because of tremendous typhoons, so the number of sample clones of each species with at least one ramet and the number of seed sources constituting the clones were 19 and 17 for $A$. mangium and 23 and 8 for $A$. auriculiformis, respectively. The number of ramets used for each clone is shown in Tables 2 and 3 . The height of each ramet was maintained at $3 \mathrm{~m}$ by pruning for easy observation of flowers.

\section{Investigation of flowering period}

In 2006 and 2007, we roughly observed the flowering period of sample ramets, with the result that, on some ramets, flowering continued from November to January of the next year. This observation suggests that if one season within a year was regarded as being from January to December, the flowering period could not be specified on the ramets whose flowering period was spread over parts of two consecutive years. Therefore, as a reference of this observation, in this paper, one season is regarded as being from April to March of the following year; the period from April 2008 to March 2009 is shown as the '2008 season', the period from April 2009 to

Table 2. - Sample clones, seed source of the clone, number of ramets examined, and location of the seed source for A. mangium.

\begin{tabular}{|c|c|c|c|c|c|}
\hline Clone & Seed source & $\begin{array}{l}\text { Vumber of } \\
\text { ramets } \\
\text { examined }\end{array}$ & I.at. ${ }^{1}$ & $\log _{2}{ }^{2}$ & Att." \\
\hline 506 & $\Lambda\left(Q L D^{4}\right)$ & 2 & $1554 \mathrm{~S}$ & $14521 \mathrm{E}$ & 50 \\
\hline $5 / 2$ & $B(Q[D)$ & 2 & $1814 \mathrm{~S}$ & $14557 \mathrm{~F}$ & 18 \\
\hline 514 & C(QLD) & 2 & $1857 \mathrm{~S}$ & $14617 !$ & 20 \\
\hline 516 & $D(Q L D)$ & 2 & $1628 \mathrm{~S}$ & $14522 \mathrm{E}$ & 7 \\
\hline 525 & $1:\left(P N G^{5}\right)$ & 2 & \multirow{2}{*}{$0837 \mathrm{~S}$} & \multirow{2}{*}{$14247 \mathrm{H}$} & \multirow{2}{*}{40} \\
\hline 526 & $\mathrm{~L}(\mathrm{PNG})$ & 2 & & & \\
\hline 527 & $\mathrm{~F}(\mathrm{QLD})$ & 2 & $1203 \mathrm{~S}$ & $14232 \mathrm{E}$ & 50 \\
\hline 531 & G(QLD) & 1 & $1244 \mathrm{~S}$ & $14316 \mathrm{E}$ & 30 \\
\hline 538 & II(PVG) & 2 & $0841 \mathrm{~S}$ & 141511: & 15 \\
\hline 541 & $\mathrm{I}(\mathrm{PNC})$ & 2 & $0902 S$ & $14304 \mathrm{~F}$ & 10 \\
\hline 544 & $J(P N G)$ & 1 & $0819 \mathrm{~S}$ & $14302 \mathrm{E}$ & 10 \\
\hline 562 & $K(P N G)$ & 2 & \multirow{2}{*}{$0850 \mathrm{~S}$} & \multirow{2}{*}{$14305 \mathrm{E}$} & \multirow{2}{*}{10} \\
\hline 563 & $K(P \vee G)$ & 1 & & & \\
\hline 566 & $\mathrm{I}(\mathrm{PNG})$ & 2 & $0805 \mathrm{~S}$ & $14258 \mathrm{~F}$ & 15 \\
\hline 567 & $\mathrm{M}(\mathrm{PNC})$ & 2 & $0840 \mathrm{~S}$ & $14243 \mathrm{E}$ & 45 \\
\hline 572 & $N(Q L D)$ & 1 & $1234 \mathrm{~S}$ & $14309 \mathrm{E}$ & 20 \\
\hline 576 & $O(P Y G)$ & 2 & $0700 \mathrm{~S}$ & 14133E: & 50 \\
\hline 580 & $\mathrm{P}(\mathrm{PNG})$ & 1 & 08495 & $14300 \mathrm{~F}$ & 10 \\
\hline 581 & Q(PNG) & 1 & $0900 \mathrm{~S}$ & $14154 \mathrm{E}$ & 20 \\
\hline
\end{tabular}

1, Latitude (South or North): 2, Longitude (East or West): 3, Altitude: 4, Queensland: 5, Papua New Guinea.
Table 3. - Sample clones, seed source of the clone, number of ramets examined, and location of the seed source for A. auriculiformis.

\begin{tabular}{|c|c|c|c|c|c|}
\hline Clone & Seed souree & $\begin{array}{l}\text { Vumber of } \\
\text { ramets } \\
\text { examined }\end{array}$ & Lat. & Log. & Nlt. \\
\hline 101 & $\mathrm{~d}(\mathrm{Q} \mathrm{I} . \mathrm{I})$ & 2 & \multirow{2}{*}{$1326 \mathrm{~S}$} & \multirow{2}{*}{$14257 \mathrm{~F}$} & \multirow{2}{*}{90} \\
\hline 107 & $\mathrm{a}(\mathrm{Q}, \mathrm{L})$ & 1 & & & \\
\hline 111 & $b(Q L D)$ & 2 & \multirow{5}{*}{$1211 \mathrm{~s}$} & \multirow{5}{*}{$14259 \mathrm{E}$} & \multirow{5}{*}{4} \\
\hline 112 & b(QL.D) & 1 & & & \\
\hline 114 & $b(\mathbf{Q L D})$ & 2 & & & \\
\hline 115 & b(QI.D) & 2 & & & \\
\hline 116 & $b($ QLD $)$ & 1 & & & \\
\hline 122 & $\mathrm{c}(\mathrm{QI}, \mathrm{D})$ & ] & \multirow{2}{*}{$1305 \mathrm{~S}$} & \multirow{2}{*}{$14251 \mathrm{~F}$} & \multirow{2}{*}{120} \\
\hline 123 & (QLD) & 1 & & & \\
\hline 125 & $\mathrm{~d}\left(\mathrm{NT}^{\mathrm{j}}\right)$ & 2 & \multirow{2}{*}{$1134 \mathrm{~S}$} & \multirow{2}{*}{$13034 \mathrm{~F}$} & \multirow{2}{*}{20} \\
\hline 126 & $\mathrm{~d}(\mathrm{NT})$ & 2 & & & \\
\hline 130 & (PNG) & 2 & \multirow{2}{*}{$850 \mathrm{~S}$} & \multirow{2}{*}{ 14138F } & \multirow{2}{*}{18} \\
\hline 131 & e(PNC) & 2 & & & \\
\hline 135 & $f(Q L D)$ & 2 & \multirow{3}{*}{$1552 \mathrm{~S}$} & \multirow{3}{*}{$14453 \mathrm{~F}$} & \multirow{3}{*}{240} \\
\hline 136 & f(QI.D) & 2 & & & \\
\hline 137 & (IQLD) & 2 & & & \\
\hline 146 & g(Thailand) & 1 & \multirow{4}{*}{$1235 \mathrm{~N}$} & \multirow{4}{*}{$101151:$} & \multirow{4}{*}{0} \\
\hline 147 & g(Thailand) & 2 & & & \\
\hline 148 & g(Thailand) & 2 & & & \\
\hline 149 & g(Thailand) & 1 & & & \\
\hline 151 & $h(\mathrm{QI} . \mathrm{I})$ & 2 & \multirow{3}{*}{$1234 \mathrm{~S}$} & \multirow{3}{*}{$14310 E$} & \multirow{3}{*}{20} \\
\hline 152 & $h(Q L D)$ & 2 & & & \\
\hline 153 & $\mathrm{~h}(\mathrm{QLD})$ & 2 & & & \\
\hline
\end{tabular}

1, Northern Territory of Australia.

March 2010 is shown as the '2009 season', and the period from April 2010 to March 2011 is shown as the '2010 season'.

From April 2008 to March 2011, the flowering of each ramet was visually observed every 3 or 4 days. By this observation, we could know both the flowering initiation and flowering period of each ramet for each season. The unit we used for a flowering period was an interval of ' 10 days', which was regarded as one period so that if the flowering initiation took place in early September and the flowering termination took place in late December, the flowering initiation (divided into early-, mid-, and late-month) and the flowering period are shown as 'early Sept., 12'. The percentage of flowering for each clone in each season was calculated by dividing the number of flowering ramets by the number of ramets used.

\section{Pollen collection and germination test}

To collect pollen from A. mangium and A. auriculiformis ramets, a tube (bore, $0.5 \mathrm{~cm}$; length, $7 \mathrm{~cm}$ ) was inserted into a spike when nearly all flowers on the spike had bloomed. To collect as many pollen grains as possible, the tube was moved up and down in the spikes 5 to 10 times, and pollen was collected from each clone, regardless of the ramet. Tubes containing very little pollen by observation with binoculars were excluded from the germination test. Following pollen collection, a tube was covered with medicine paper and immediately stored at $-18^{\circ} \mathrm{C}$ until later being subjected to germination tests. 
Germination tests were conducted at 1 day, 6 months, and 12 months from the time of pollen collection, as previously described (YAMAGUCHI and OGAWA, 2008). Briefly, pollen was removed from the stored tubes using a brush, and was then dropped on the surface of a medium consisting of $20 \%$ sucrose and $1 \%$ agar in a petri dish. Following incubation at $23^{\circ} \mathrm{C}$ for $48 \mathrm{~h}$, the condition of the polyads that consisted of 16 pollen grains was examined under a microscope. Polyads with at least one extended pollen tube were considered germinated. Five spikes were used for a germination test for each storage period, and if the number of available sample tubes was less than 15 for each clone of each season, germination tests were canceled when the range of available tubes was between zero and nine; germination tests 6 months after collection were canceled when the range of available tubes was between 10 and 14. The mean germination rate of each clone was calculated for each storage period investigated.

\section{Statistical analysis}

Seasonal fluctuations were compared from the mean percentage of flowering per clone using the $t$-test, and from the flowering initiation and flowering period using the Kruskal-wallis test. The mean percentage of flowering per clone, the flowering initiation and the flowering period were compared among clones and seed sources, and within seed sources using the Kruskal-wallis test. Multiple comparison tests were conducted among A. auriculiformis clones and seed sources on flowering initiation and the flowering period (SIEGEL and CASTELLAN, 1988). The germination rates of pollens were compared among clones and seed sources, and within seed sources in relation to pollen storage periods and seasons using one- or two-way ANOVA. Furthermore, a significant decrease in the germination rate of pollens with an increase in storage days for each clone was calculated using the $t$-test. All statistical analyses were performed using STATISTICA version 6 (StatSoft Inc. Tulsa, OK).

\section{Results}

\section{Flowering phenology}

After layering, no ramets flowered until 2008 on A. mangium, whereas ramets flowered from 2006 on A. auriculiformis. During the flowering period of each ramet, flowering continued without a break for all sample ramets for all seasons. The mean percentage of flowering per clone was low for all seasons on A. mangium and did not show significant variations among the seasons ( $t$-test; $t=1.1$ to $1.8, P>0.05$ ) (Table 4 ). On the other hand, the mean percentage of flowering per clone was greater than $60 \%$ for all seasons on A. auriculiformis and did not show significant variations among the seasons ( $t$-test; $t=0.3$ to $1.0, P>0.05$ ) (Table 5). Clones 525, 576, 112, 114, 116, 122, 126, 131, 136, 137, and 153 did not flower in a single season, even if those ramets had flowered in the previous season. For seed source $\mathrm{g}$ all ramets flowered for all seasons.

The flowering initiation on any ramet varied with the seasons on both tree species; in December (clones 525 and 576) for the 2008 season and in September (clone
Table 4. - Sample clones, seed source of the clone, number of ramets examined, and location of the seed source for A. auriculiformis.

\begin{tabular}{|c|c|c|c|c|c|}
\hline Clone & Seed souree & $\begin{array}{l}\text { Number of } \\
\text { ramets } \\
\text { examined }\end{array}$ & Lat. & Log. & All. \\
\hline 101 & $\mathrm{a}(\mathrm{Q} L \mathrm{D})$ & 2 & \multirow{2}{*}{$1326 \mathrm{~S}$} & \multirow{2}{*}{$14257 \mathrm{E}$} & \multirow{2}{*}{90} \\
\hline 107 & $\mathrm{a}(\mathrm{Q} I \mathrm{D})$ & 1 & & & \\
\hline 111 & $b(Q I D)$ & 2 & \multirow{5}{*}{$1211 \mathrm{~S}$} & \multirow{5}{*}{$14259 \mathrm{~F}$} & \multirow{5}{*}{4} \\
\hline 112 & $b(Q I D)$ & 1 & & & \\
\hline 114 & $b(Q L D)$ & 2 & & & \\
\hline 115 & $b(Q L D)$ & 2 & & & \\
\hline 116 & $b(Q L D)$ & 1 & & & \\
\hline 122 & $c(Q L D)$ & 1 & \multirow{2}{*}{$1305 \mathrm{~S}$} & \multirow{2}{*}{$14251 \mathrm{E}$} & \multirow{2}{*}{120} \\
\hline 123 & $c(Q I D)$ & 1 & & & \\
\hline 125 & $\mathrm{~d}\left(\mathrm{NT}^{\prime}\right)$ & 2 & \multirow{2}{*}{$1134 \mathrm{~S}$} & \multirow{2}{*}{$13034 \mathrm{E}$} & \multirow{2}{*}{20} \\
\hline 126 & $d(N T)$ & 2 & & & \\
\hline 130 & $e(P \vee G)$ & 2 & \multirow{2}{*}{$850 \mathrm{~S}$} & \multirow{2}{*}{$14138 \mathrm{E}$} & \multirow{2}{*}{18} \\
\hline 131 & $c(P Y G)$ & 2 & & & \\
\hline 135 & I(QL.D) & 2 & \multirow{3}{*}{$1552 \mathrm{~S}$} & \multirow{3}{*}{$14453 \mathrm{~F}$} & \multirow{3}{*}{240} \\
\hline 136 & R(QLD) & 2 & & & \\
\hline 137 & r(QL.D) & 2 & & & \\
\hline 146 & $\mathrm{~g}$ (Thailand) & 1 & \multirow{4}{*}{$1235 \mathrm{~N}$} & \multirow{4}{*}{101151} & \multirow{4}{*}{0} \\
\hline 147 & g( lhailand) & 2 & & & \\
\hline 148 & $\mathrm{~g}$ (Thailand) & 2 & & & \\
\hline 149 & $g$ (Thailand) & 1 & & & \\
\hline 151 & $h(Q I D)$ & 2 & \multirow{3}{*}{$1234 \mathrm{~S}$} & \multirow{3}{*}{143105} & \multirow{3}{*}{20} \\
\hline 152 & $h(Q I D)$ & 2 & & & \\
\hline 153 & $h(Q I D)$ & 2 & & & \\
\hline
\end{tabular}

1, Northern Territory of Australia.

Table 5. - Percentage of flowering on each A. auriculiformis clone.

\begin{tabular}{|c|c|c|c|c|}
\hline Clone & Seed source & $\begin{array}{l}2008(\Lambda \mathrm{pr} .) \\
2009(\mathrm{Mar} .)\end{array}$ & $\begin{array}{l}2000(\Lambda \mathrm{pr} .) \\
2010(\mathrm{Mar} .)\end{array}$ & $\begin{array}{l}2010(\Lambda \mathrm{pr}) \\
2011 \text { (Mar.) }\end{array}$ \\
\hline 101 & a & 100 & 100 & 100 \\
\hline 107 & $a$ & 0 & 0 & 0 \\
\hline 111 & $b$ & 0 & 50 & 50 \\
\hline 112 & $b$ & 100 & 100 & 0 \\
\hline 114 & $b$ & 100 & 0 & 0 \\
\hline 115 & $b$ & 0 & 100 & 100 \\
\hline 116 & $\mathrm{~b}$ & 100 & 100 & 0 \\
\hline 122 & $\mathrm{c}$ & 100 & 0 & 0 \\
\hline 123 & $\mathrm{c}$ & 0 & 100 & 100 \\
\hline 125 & $d$ & 100 & 100 & 100 \\
\hline 126 & $\mathrm{~d}$ & 100 & 0 & 50 \\
\hline 130 & $\mathrm{e}$ & 50 & 100 & 100 \\
\hline 131 & $\mathrm{e}$ & 0 & 50 & 0 \\
\hline 135 & i & 0 & 100 & 100 \\
\hline 136 & 「 & 50 & 100 & 50 \\
\hline 137 & $\mathrm{f}$ & 0 & 100 & 0 \\
\hline 146 & $g$ & 100 & 100 & 100 \\
\hline 147 & $y$ & 100 & 100 & 100 \\
\hline 148 & $g$ & 100 & 100 & 100 \\
\hline 149 & $\mathrm{~g}$ & 100 & 100 & 100 \\
\hline 151 & $\mathrm{~h}$ & 100 & 100 & 100 \\
\hline 152 & $\mathrm{~h}$ & 100 & 100 & 100 \\
\hline 153 & $\mathrm{~h}$ & 100 & 0 & 50 \\
\hline Mean-SE & & $65.2 \perp 9.7$ & $73.9 \perp 8.8$ & $60.9-9.4$ \\
\hline
\end{tabular}

Mean percentage of flowering is calculated by dividing the number of flowering ramets by the number of ramets used. 
525) for the 2010 season on A. mangium; and in July (clone 148) for the 2008 season, in September (clones 147 and 148) for the 2009 season, and in August (clones 147 and 148) for the 2010 season on A. auriculiformis, but the overall flowering initiation did not show significant variations among the investigated seasons on either tree species (Kruskal-wallis test, $\chi^{2}=3.6$ and 2.1, respectively, $P>0.05$ ) (Tables 6 and 7).

Similarly, the longest flowering period on any ramet differed depending on the season on both tree species: 1 unit (clones 525 and 576) in the 2008 season and 5 units (clone 512) in the 2010 season on A. mangium; and 17 units (clone 148) in the 2008 season, 8 units (clone 148 and 152) in the 2009 season, and 17 units (clone 147) in the 2010 season on $A$. auriculiformis. However, the overall flowering period did not show significant variations among the investigated seasons on either tree species (Kruskal-wallis test, $\chi^{2}=2.2$ and 0.7 , respectively, $P>0.05)$.

Table 8 shows the results of a Kruskal-wallis test for detecting the variations on the percentage of flowering per clone, the flowering initiation, and the flowering period among clones and seed sources, and within each seed source on both tree species, using all the data for the three seasons combined. The percentage of flowering per clone did not show significant variations among clones and seed sources, or within seed sources on $A$. mangium $(P>0.05)$. On the other hand, it did not show

Table 6. - Flowering initiation and flowering period on each A. mangium ramet.

\begin{tabular}{|c|c|c|c|c|}
\hline Clone & Seed source & $\begin{array}{l}2008(\mathrm{Apr}) \\
2009(\mathrm{Mar})\end{array}$ & $\begin{array}{l}2009(\mathrm{Apr}) \\
2010(\mathrm{Mar})\end{array}$ & $\begin{array}{l}2010(\mathrm{Apr}) \\
2011 \text { (Mar })\end{array}$ \\
\hline 512 & $B$ & & & early (Oct., 5 \\
\hline 512 & $\sqrt{3}$ & & & carly Noy, 2 \\
\hline 525 & $\mathrm{~F}$. & mid Dec., l & & mid Sept., 4 \\
\hline 525 & F: & & & mid Sept., 1 \\
\hline 576 & 0 & mid Dec., 1 & & \\
\hline 581 & $Q$ & & & mid ()et., I \\
\hline
\end{tabular}

Ramets with no flowering for three years are not listed.
Table 7. - Flowering initiation and flowering period on each A. auriculiformis ramet.

\begin{tabular}{|c|c|c|c|c|}
\hline Clone & Seed source & $\begin{array}{l}2008(\text { ( pr. })- \\
2009 \text { (Mar.) }\end{array}$ & $\begin{array}{l}2009(\mathrm{Apr})- \\
2010(\mathrm{Mar})\end{array}$ & $\begin{array}{l}2010(\text { (Nr.) } \\
2011 \text { (Mar.) }\end{array}$ \\
\hline 101 & a & early Nov, 9 & mid Nov., 4 & early Dec.. 2 \\
\hline 101 & a & mid Dec., 2 & late Nov., 3 & carly Dec., 3 \\
\hline 111 & $b$ & & late Dec., 3 & early Dec., ] \\
\hline 112 & $b$ & early Janl., 1 & mid Jan., 2 & \\
\hline 114 & $b$ & late Dec., 2 & & \\
\hline 114 & b & early Jan., 1 & & \\
\hline 115 & $b$ & & late IDec, 4 & mid I)ec. 6 \\
\hline 115 & b & & mid Jan., 1 & late Dec. 4 \\
\hline 116 & $b$ & carly Jan., 1 & mid Dec., 5 & \\
\hline 122 & c & carly Jan.. 1 & & \\
\hline 123 & $c$ & & late Nove., 6 & early IDec., 7 \\
\hline 125 & d & early Jan., 1 & early Dee., 4 & early Dec., 2 \\
\hline 125 & $d$ & carly Jan, 3 & mid Dec.. 3 & edrly Dec., 2 \\
\hline 126 & d & late Dec., 2 & & early Dec., 5 \\
\hline 126 & d & late Nov.. 5 & & \\
\hline 1.30 & e & late Nov., 5 & early Nor, 4 & late Oct., 5 \\
\hline 130 & e & & mjal Dee.. 1 & Inid Dec, 2 \\
\hline 1.31 & e & & late Dec., 2 & \\
\hline 135 & $\mathrm{f}$ & & late Dec., 4 & late Dec., 2 \\
\hline 135 & $\Gamma$ & & mid Jan., 3 & carly Fob, I \\
\hline 136 & $\mathrm{f}$ & early Jan., 2 & early Dec., 6 & mid Dec., 5 \\
\hline 136 & $\Gamma$ & & mid Jan.. I & \\
\hline 137 & $f$ & & mid Jan., 4 & \\
\hline 137 & I & & mid Dec., 6 & \\
\hline 146 & $g$ & mid Aug., 9 & carly Sept.. 13 & early Aug., 11 \\
\hline 147 & $\mathrm{~g}$ & late Oct., 1 & late Sept., 7 & mid Sept.. 9 \\
\hline 147 & $g$ & carly Stpt., 6 & lates Sept., 7 & mid Aug, 17 \\
\hline 148 & $\mathrm{~g}$ & late July, 17 & early Oct.. 8 & late $\Lambda$ ug., 12 \\
\hline 148 & $g$ & mid Aug. 12 & late Sept. 8 & late Aug., 15 \\
\hline 149 & $\mathrm{~g}$ & mid Ocl., 6 & carly Sept., 10 & late Aug., 12 \\
\hline 151 & h & late Oct., 6 & mid Nov., 3 & early No4., 5 \\
\hline 151 & b & late Oct., 7 & mid Vov, 5 & mid liow, 3 \\
\hline 152 & h & late Dec., 4 & late Nov., 8 & mid Dec., l \\
\hline 152 & $\mathrm{~h}$ & mid Dec.. 5 & mid Dec., 7 & carly Dec., 9 \\
\hline 153 & $\mathrm{~h}$ & mid Dec., 2 & & mid Jan., 1 \\
\hline 153 & $\mathrm{~h}$ & late Dec., 3 & & \\
\hline
\end{tabular}

Ramets with no flowering for three years are not listed.

Table 8. - Results of Kruskal-wallis test $\left(\chi^{2}\right)$ for detecting variations among clones, seed sources, and within seed sources on percentgae of flowering, flowering initiation and flowering period for both tree species.

\begin{tabular}{|c|c|c|c|c|c|c|}
\hline \multirow{2}{*}{ [tems } & \multicolumn{2}{|c|}{ Perecntage of flowering } & \multicolumn{2}{|c|}{ Flowering initiation } & \multicolumn{2}{|c|}{ Flowering period } \\
\hline & 1. magium & 1. auric uliformis & 1. magiam & A. auriculiformis & 1. magium & A. curiculiformis \\
\hline Clones & 23.] & 33.3 & 1.6 & $63.8^{* *}$ & 2.4 & $44.4^{* *}$ \\
\hline Seed sources & 15.1 & $20.5^{* *}$ & 1.6 & $54.5^{* *}$ & 2.4 & $34.3^{* *}$ \\
\hline Sced source E & 2.4 & & & & & \\
\hline Seed source $K$ & 0 & & & & & \\
\hline Seed source a & & $5.0 *$ & & & & \\
\hline Seed source b & & 1.8 & & 4.2 & & 2,6 \\
\hline Seed source c & & 0.6 & & 1.5 & & 1.5 \\
\hline Seed source d & & 2.4 & & 0.9 & & 1.0 \\
\hline Seed source e & & 3.3 & & 2.2 & & 0.4 \\
\hline Seed source $f$ & & 0.9 & & 1.3 & & 2.3 \\
\hline Sced sourceg & & 0 & & 3.9 & & 4.0 \\
\hline Seed source h & & 4.5 & & $11.3^{* *}$ & & 4.7 \\
\hline
\end{tabular}

**: $P<0.01,{ }^{*}: P<0.05$. 
significant variations among clones $(P>0.05)$, but did show significant variations among seed sources and within one of seven seed sources on $A$. auriculiformis $(P<0.05)$.

The flowering initiation did not show significant variations among clones and seed sources on A. mangium

Table 9. - Germination rates of pollens (mean \pm SE) on each A. mangium clone.

\begin{tabular}{|c|c|c|c|c|}
\hline \multirow{3}{*}{ Clene } & \multirow{2}{*}{\multicolumn{3}{|c|}{$\begin{array}{l}2010(\mathrm{Apr} \text {.) }-2011 \text { (Mar.) } \\
\text { Stored days of pollens }\end{array}$}} & \multirow{3}{*}{$\begin{array}{l}F \text { (Among stored } \\
\text { days in 2008) }\end{array}$} \\
\hline & & & & \\
\hline & 0 & 180 & 360 & \\
\hline 101 & $52.8 \div 4.1$ & $15.9 \div 2.8$ & $33.3+3.9$ & $25.9^{\text {*** }}$ \\
\hline 111 & $20.5 \div 3.0$ & $9.8 \cdot 2.0$ & $10.9 \perp 2.6$ & $5.2^{*}$ \\
\hline $\begin{array}{l}\mathrm{F} \text { (Among } \\
\text { clones) }\end{array}$ & $41.5^{* 8}$ & 3.2 & $22.2^{* *}$ & \\
\hline
\end{tabular}

$(P>0.05)$. On the other hand, it showed significant variations among clones and seed sources, and also within one of seven seed sources on $A$. auriculiformis $(P<0.05)$. The results of multiple comparison tests among the clones indicated that the flowering initiation on clones 147 and 148 were significantly earlier than that on clone $135(P<0.05)$. Similarly, those results among seed sources indicated that the flowering initiation on seed source $g$ were significantly earlier than those on the seed sources b, d, f, and h $(P<0.05)$.

The flowering period did not show significant differences among clones and seed sources on $A$. mangium $(P>0.05)$. On the other hand, it did show significant differences among clones and seed sources $(P<0.05)$, but did not show significant differences within seed sources, on $A$. auriculiformis $(P>0.05)$. The results of multiple comparison tests among clones indicated that there were no significant differences in the flowering period $(P<0.05)$. However, those results among seed sources

Table 10. - Germination rates of pollens (mean $\pm \mathrm{SE}$ ) on each A. auriculiformis clone.

\begin{tabular}{|c|c|c|c|c|c|c|c|c|c|c|c|c|c|}
\hline \multirow{3}{*}{ Clone } & \multirow{2}{*}{\multicolumn{3}{|c|}{$\frac{200 \mathrm{R}\left(\wedge_{\mathrm{pr}} \text {-) }-200 \%(\mathrm{Mar})\right.}{\text { Stured days of polleris }}$}} & \multirow{3}{*}{ 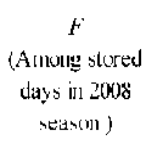 } & \multirow{2}{*}{\multicolumn{3}{|c|}{$\begin{array}{l}3009(\text { A pr. })-20 \text { lo(Mar.) } \\
\text { scored days of polleuss }\end{array}$}} & \multirow{3}{*}{ 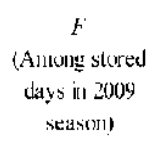 } & \multirow{2}{*}{\multicolumn{3}{|c|}{ 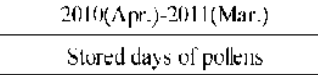 }} & \multirow{3}{*}{$\begin{array}{c}F \\
\text { (Amolys stured } \\
\text { days in } 2010 \\
\text { sedstrs] }\end{array}$} & \multirow{3}{*}{$\begin{array}{c}F \\
\text { (Alunual } \\
\text { fluctuation) }\end{array}$} \\
\hline & & & & & & & & & & & & & \\
\hline & 0 & 180 & 360 & & 0 & 180 & 360 & & 0 & 180 & 360 & & \\
\hline 101 & & & & & 79.512 .1 & $88.8: 1.9$ & $50.9: 5.5$ & $9.4^{409}$ & $95.2+2.0$ & 68.113 .6 & $77.8: 5.9$ & $10.8^{\mathrm{en}}$ & 2.0 \\
\hline 111 & & & & & $69.5 \pm 2.9$ & $60.6=14.6$ & 46.95 .5 .1 & 2.2 & & & & & \\
\hline 112 & & & & & $85.5 \pm 1.6$ & $65.0=1.0$ & $93.3=0.4$ & $170^{\circ}$ & & & & & \\
\hline 114 & 660157 & 66.115 .6 & $662 \cdot 69$ & 0.1 & & & & & & & & & \\
\hline 115 & & & & & $53.1 \pm 8.6$ & $25.7=8.8$ & $581=5.3$ & 22 & $73.2 \pm 5.7$ & $93.1 \pm 109$ & $95.3=10$ & $13.1^{* \prime}$ & $31.0^{4+}$ \\
\hline 116 & & . & & & 57.618 .5 & & $40.9-4.4$ & 2.1 & & & & & \\
\hline $\begin{array}{l}\text { F (Within } \\
\text { seed source) }\end{array}$ & & & & & 2.3 & $5.6^{\circ}$ & $29.9^{N 8}$ & & & & & & \\
\hline 123 & & & & & 83.312 .1 & $74.7 \div 57$ & $86.7 \cdot 2.0$ & & 86.711 .0 & 64.216 .2 & $87.4 \cdot 2.2$ & $11.7^{\mathrm{tx}}$ & 1.9 \\
\hline 125 & $27.3 \perp 5.7$ & $10.5 \perp 5.8$ & $43.8 \div 6.4$ & $63.6^{*+}$ & $36.6 \pm 5.4$ & $33.3<54$ & $84.6-1.9$ & 2.1 & $81.9 \pm 3.2$ & $42.4+7.4$ & 86.62 .8 & $47.8^{e^{-n}}$ & $12,2^{4+}$ \\
\hline 126 & & & & & & & & & $85.1 \pm 1.7$ & $(0) .1 \pm 1.0$ & $y 1.5=0.7$ & $1365^{\circ \prime}$ & \\
\hline $\begin{array}{l}\text { F ( W'thin } \\
\text { sed source) }\end{array}$ & & & & & & & & & 0.8 & $14.3^{s+4}$ & 3.3 & & \\
\hline $\begin{array}{l}130 \\
131 \\
\end{array}$ & & & & & 73.015 .4 & $73.9: 3.3$ & $89.3: 1.0$ & 2.1 & $81.3+3.1$ & 76.713 .5 & $70.1: 1.7$ & 3.9 & 4.1 \\
\hline 135 & & & & & $81.2+4.4$ & $71.2 \div 4.7$ & $51.0-2.2$ & $15.3^{x+}$ & & & & & \\
\hline 136 & & & & & 85.212 .4 & $71.1: 2.6$ & $90,0: 1.5$ & $19.6^{4+}$ & $94.8+0.8$ & 84.113 .2 & $93.7: 1.2$ & $83^{*+}$ & $254^{4 *}$ \\
\hline 137 & $87(0 \pm 19$ & & $87.4=1.4$ & 0.4 & (8) $1 \pm 2.2$ & $76.1=1.7$ & $82.2=50$ & 3.8 & & & & & 0.1 \\
\hline $\begin{array}{l}\text { Fo (Within } \\
\text { seed scoures) }\end{array}$ & & & & & 1.5 & 0.8 & $39.1^{* x}$ & & & & & & \\
\hline $1 / 46$ & $55, \bar{z} \pm 7.8$ & $11,7 \pm 7.8$ & $37,2=53$ & 1.7 & $39,1 \pm \mathbf{I}, 1$ & $39.8=69$ & $19.9=7.1$ & 1,1 & $5.0 \pm 1,3$ & $8.2 \pm 1.7$ & $13.1=2.5$ & 1.7 & $28.9^{4 t}$ \\
\hline 147 & & & & & $62.1 \pm+4.1$ & $62.7=5.0$ & 64.)=3.9$ & $(1.8$ & $33.4 \pm 4.2$ & $37.7 \pm .56$ & $1 \hbar . y=2.9$ & $9.6^{\circ "}$ & $116.4^{\circ "}$ \\
\hline 148 & $53,5 \pm 4 ;$ & $67,7 \pm 2,2$ & $369=4.3$ & $5.3^{4 t}$ & $21,8 \pm \overline{3} 3$ & $54.9=7.7$ & $63.4=3.4$ & $8.9^{\text {int }}$ & $5.0 \pm 1,9$ & $15.4 \pm 3.3$ & $18.4=4.8$ & $1.0^{\circ}$ & $13.5^{4 *}$ \\
\hline 149 & & & & & 73.314 .8 & & $31.8-9.7$ & $84^{4}$ & $91.3 \perp 0.6$ & $77.4 \perp 1.3$ & 77.84 .1 & $98^{4}$ & $17.8^{* *}$ \\
\hline $\begin{array}{c}\text { F (Within } \\
\text { seed sourec) }\end{array}$ & 0.0 & $8.0^{\circ}$ & 0.6 & & $9.00^{\circ "}$ & 0.2 & $5.6^{\circ "}$ & & $287.8^{\prime \prime 8}$ & $137.6^{.3}$ & $70.1^{30}$ & & \\
\hline 151 & $63.1 \pm 7.5$ & & $90.8=1.7$ & $21.9^{\circ}$ & $72.8 \pm 1.4$ & $87.1=2.9$ & $80.4=3.3$ & $7.1^{\prime \prime \prime}$ & 19].2 $2 \pm 1.7$ & $43.6 \pm 2.7$ & $68.4=16.1$ & $15.1^{\circ \prime}$ & 0.2 \\
\hline 152 & $95.7 \perp 0.8$ & $81.3 \perp 3.4$ & $89.2-30$ & $8.9^{4.8}$ & 53.315 .2 & $67.0-12.1$ & $50.7-1.7$ & 1.3 & 84.311 .6 & $58.1 \perp 64$ & $91.0-1.8$ & $19.1^{62}$ & $32.7^{4+}$ \\
\hline 153 & $27.9 \pm 4.6$ & & $21.8=6.7$ & $(1.1$ & & & & & & & & & \\
\hline $\begin{array}{l}\text { F ( Within } \\
\text { seed souree ) }\end{array}$ & $111.4^{4 *}$ & & $74.3^{\circ *}$ & & $13.0^{\circ "}$ & 2.6 & $64.2^{4 \times 4}$ & & $9.1^{4}$ & 4.4 & 4.9 & & \\
\hline $\begin{array}{l}\text { F Among } \\
\text { clancs })\end{array}$ & $8.4^{3+}$ & $26.9^{+*}$ & $9.1^{+*}$ & & $x .0^{+2+}$ & $5.5^{+4+1}$ & $5.6^{* 4}$ & & $1.57 .6^{x^{*}}$ & $49.2^{* *}$ & $5 \times .9^{1 *}$ & & \\
\hline $\begin{array}{l}F \quad \text { (Among } \\
\text { seed soluces) }\end{array}$ & $7.4^{3+}$ & $235^{* *}$ & $7.5^{+4}$ & & $7.5^{4 \prime \prime}$ & $74^{4 \times x}$ & $2.8^{*}$ & & $12.0^{* *}$ & $10.0^{3 *}$ & $17.1^{38}$ & & \\
\hline
\end{tabular}

**: $P<0.01,{ }^{*}: P<0.05$. 
indicated that the flowering period on seed source $g$ were significantly longer than those on seed sources $b$, $\mathrm{d}$, e, and $\mathrm{h}(P<0.05)$.

\section{Germination rate of pollens}

The number of clones available for germination testing was 2 in the 2010 season on $A$. mangium, and 8,17 , and 13 in the 2008, 2009, and 2010 seasons on A. auriculiformis, respectively. The germination rates of pollens per clone in the 2010 season were $52.8 \%$ and $20.5 \% 1$ day after being stored, $15.9 \%$ and $9.8 \%$ after 6 months, and $33.3 \%$ and $10.9 \%$ after 12 months on $A$. mangium (Table 9). On the other hand, the rates ranged from 27 to $95 \%$ in the 2008 season, 21 to $89 \%$ in the 2009 season, and 5 to $95 \%$ in the 2010 season 1 day after being stored; ranged from 10 to $81 \%$ in 2008,25 to $88 \%$ in 2009 , and 15 to $93 \%$ in 2010 after 6 months; and ranged 24 to $90 \%$ in 2008,46 to $90 \%$ in 2009 , and 16 to $95 \%$ in 2010 after 12 months on A. auriculiformis (Table 10). The pollen germination rates were generally consistent among sample spikes on each day that was investigated for all clones, because of the low levels of standard errors (mostly less than 10). On the other hand, the pollen germination rates showed significant differences among clones for all seasons and for all storage periods, with the exception of one case of $A$. mangium that was stored for 6 months (one-way ANOVA, $F=5.5$ to 157.6, $P<0.01$ ). Also, the pollen germination rates showed significant differences in 15 of 26 available cases within seed sources (one-way ANOVA, $F=5.6$ to $287.8, P<0.05$ ).

The pollen germination rates varied significantly among the stored days of pollens in about half of the clones in the 2008 and 2009 seasons, and in all but two clones (130 and 146) in the 2010 season, 24 cases in total (one-way ANOVA, $F=4.0$ to $136.5, P<0.01$ ). In nine of these 24 cases, for significant variance, the pollen germination rates decreased significantly after 12 months in storage ( $t$-test, $t=2.6$ to $6.1, P<0.05$ ). Furthermore, significant seasonal fluctuations for the pollen germination rates were detected in eight out of 13 clones (twoway ANOVA, $F=12.2$ to $116.4, P<0.01$ ).

\section{Discussion}

As was the case in the report on the variation in growth rates of $A$. auriculiformis among seed sources (RYAN et al., 1991), we have detected variations or differences in the flowering phenology of A. auriculiformis, such as the percentage of flowering per clone, the flowering initiation, and the flowering period, not only among the clones but also among the seed sources, compared to within the seed sources (Tables 5, 7, and 8). Therefore, as stated in the report on tree species such as Taraxacum officinale and Olea europaea (COLLIER and ROGSTAD, 2004; GARCIA-Mozo et al., 2009), genetic factors also in some degree affect the flowering phenology of $A$. auriculiformis.

On A. mangium, however, we could not detect significant variations or differences in the flowering phenology due to the low percentage of flowering per clone (Tables 4, 6 and 8). SEDGLEY et al. (1991b) mentioned that, on dry sites, A. mangium produced fewer flowers than
A. auriculiformis. Although this study's experimental area is generally wet, judging from the mean annual precipitation (Table 1), all ramets were potted for easy transport whenever typhoons were nearby. This regimen may cause ramets to have very dry conditions and thus suppress the flowering of $A$. mangium. Therefore, we are now examining whether most of the $A$. mangium sampled in this study will flower when plenty of water is applied.

SEDGLEY et al. (1991a) found a single major peak between March and May for both species in Atherton, Australia compared with major peaks in Malaysia in January and July-August for A. mangium and A. auriculiformis, respectively. Similarly, KIANG et al. (1989) reported that in Taiwan, near the Iriomote Tropical Forest Tree Breeding Technical Garden, the flowering period of both species overlapped between October and November. These results suggest that in sub-tropical areas like Atherton, Taiwan and Iriomote Island with annual fluctuations in temperature, the flowering period of both species is synchronized in a manner unlike that of tropical areas like Malaysia. In this study, the flowering period of both species also overlaps in the 2008 and 2010 seasons, but the period is apparently longer for A. auriculiformis. NoR-AINI et al. (2006) reported that genetic variation is wider on $A$. auriculiformis than on $A$. mangium. This suggests that even if the percentage of flowering per clone increases on sampled $A$. mangium by applying water, the variations or differences in the flowering phenology of $A$. mangium are not as broad as those of $A$. auriculiformis because of narrow genetic variations.

From the results on the percentage of flowering per clone, we have detected that both $A$. mangium and A. auriculiformis ramets do not always flower each year on most of the seed sources (Tables 4 and 5). Sakai (2001) reported that only $29 \%$ of tropical trees showed an annual flowering pattern, suggesting that the irregular annual flowering pattern of the tree species is a general trait of tropical trees. The same irregular annual flowering trait is also reported in other species of the Acacia genus (EDDY and JUDD, 2003). On both tree species, SEDGLEY et al. (1992) investigated the flowering phenology of 10 trees for 3 years in northern Queensland and reported that in the third year the overall flowering period was shorter compared with other years investigated, and also that only four A. mangium and three $A$. auriculiformis trees flowered in the peak flowering months, suggesting that, although they did not investigate the flowering phenology of each tree, it is probable that the tree species at that site do not always flower each year. This suggests that the tree species have irregular flowering phenology traits, regardless of the planted area. Thus, although in this study there is a seed source $(\mathrm{g})$ from which all ramets flowered for all seasons, it is necessary to store pollens collected from as many male adults as possible, because we must assume that ramets used for female adults do not always flower each season.

By defining the period from April to March of the following year as one season in this study, we can detect significant variations and differences in the flowering initiation and the flowering period among seed sources 
although those are similar on some seed sources. Especially on seed source $g$, the flowering initiation occurred earlier and the flowering period was longer than that on other seed sources. This seed source is located in Thailand, where it is separated from other seed sources (Table 3). This flowering phenology may change specifically in response to the climatic condition at that site. CSIRO keeps $A$. auriculiformis seeds from more than 50 seed sources and in this study less than half of the seed sources were examined for their flowering phenology. Therefore, it is probable that more seed sources exist that show a specific flowering phenology.

If ramets originating from seed source g, which come into flower early and flower for a long period, are selected for artificial pollination, then artificial pollination can be easily conducted because of their longer flowering period. On the other hand, if ramets originating from seed sources b, d, and h, which come into flower late and flower for a short period, are selected for artificial pollination, the pollination must be conducted within a limited time because of the shorter flowering period.

On one of two A. mangium clones and most $A$. auriculiformis clones, the germination ability of stored pollens did not decrease even if the pollens were stored for 12 months using the accurate storing method reported by SEDGLey et al. (1993) (Tables 9 and 10). However, the germination ability of pollens was not as consistent among clones as in a previous report on several rose varieties (VISSER et al., 1977) and occasionally varied with the number of stored days of the pollens. KATO (2011) indicated that the germination ability of pollens 1 day after collection varied greatly among the sampling days, even if the pollens were collected from one ramet. This suggests that it is important to check the germination ability of pollens on each collection day and the number of mature seeds obtained per artificial pollination should be assumed for each cross combination by the information on the germination ability of pollens used as male adults; if the germination ability of pollens on one clone on some collection day is low, more artificial pollinations should be conducted to obtain an adequate number of mature seeds.

Furthermore, as noted in the report on the plant species Rosa hybrida (GuDIN et al., 1991), there are annual fluctuations in the germination ability of pollens on A. auriculiformis collected from the same clones. This suggests that if pollens used as male adults are collected from a ramet for several seasons, the germination ability of pollens should be investigated every season; in a season when the germination ability of pollens is low, more artificial pollinations should be conducted to obtain an adequate number of mature seeds.

Accordingly, it has been detected that there are variations in the flowering phenology among seed sources on A. auriculiformis and in the germination ability of pollens among clones on $A$. mangium and $A$. auriculiformis, and the germination ability of pollens varies among seasons on the same clones. Therefore, to obtain an adequate number of mature seeds from each cross combination, it is important to design accurate artificial pollination planning each season in order to more systematically conduct artificial pollination.

\section{Acknowledgements}

We would like to thank the staff of the Iriomote Tropical Forest Tree Breeding Technical Garden at the Forest Tree Breeding Center of the Forestry and Forest Products Research Institute for helping us in our investigation.

\section{References}

EdDY, M. R. and F. W. JudD (2003): Phenology of Acacia berlandieri, A. rigidula, A. schaffneri, and Chloroleucon ebano in the lower Rio Grande Valley of Texas during a drought. The Southwestern Naturalist 48: 321-332.

Garcia-Mozo, H., F. Orlandi, C. Galan, M. Fornaciari, B. Romano, L. Ruiz, C. D. Guardia, M. M. Trigo and I. Chuine (2009): Olive flowering phenology variation between different cultivars in Spain and Italy: modeling analysis. Theoritical Applied Climatology 95: 385-395.

Collier, M. H. and S. H. Rongstad (2004): Clonal variation in floral stage timing in the common dandelion Taxacum officinale (Asteraceae). American Journal of Botany 91: 1828-1833.

Gudin, S., L. ARENE and C. Bulard (1991): Influence of season on rose pollen quality. Sexual Plant Reproduction 4: 113-117.

Hartman, J. C., J. B. Nippert and C. J. Springer (2012): Ecotypic responses of switchgrass to altered precipitation. Functional Plant Biology 39: 126-136.

Hauser, T. P. and I. R. Weidema (2000): Extreme variation in flowering time between populations of Silene nutans. Hereditas 132: 95-101.

Josue, J. (1992): Preliminary observations on the flowering phenology and seed production in a seedling hybridizing orchard of Acacia mangium and Acacia auriculiformis. In: CARRON, L. T., AKEN, K. M , eds. Breeding technologies for tropical acacias. Canberra: Australian Centre for International Agricultural Research 37: 49-50.

KATO, K. (2011): Manual for breeding Acacia genus: Methods for establishing Acacia hybrid efficiently by artificial pollination. Forest Tree Breeding Center publ: 1-15.

KHA, L. D. (1996): Studies on natural hybrids of Acacia mangium and $A$. auriculiformis in Vietnam. In: M. J. Dieters, A. C. Matheson, D. G. Nukles, C. E. Harwood and S. M. WALKER, eds. "Tree improvement for sustainable tropical forestry". QFRI-IUFRO Conference, Caloundra, Queensland, Australia, 27 Oct.-1 Nov., 1996. Vol. 2: 328-332.

Kiang, T., C.Y. Jeng, P. Fuh-Jiunn and M. Fuh-Jing (1989): Peroxidase isozyme evidence for natural hybridization between Acacia mangium and A. auriculiformis. In: GiBson, G. L. GRIFFIN, A. R., and MAtHESON, A. C. (eds). Breeding Tropical Trees: Population Structure and Genetic Improvement Strategies in Clonal and Seeding Forestry. Pattaya, Thailand: 392-393.

KIm, N. T., J. MatsumuRA, K. ODA and N. V. CUONG (2009): Possibility of improvement in fundamental properties of wood acacia hybrids by artificial hybridization. Journal of Wood Science 55: 8-12.

Nor-Aini Ab. Shukor, K. C. Tee and C. John Keen (2006): Isozyme variation and relationships of selected Acacia species. Pakistan Journal of Biological Sciences 9: 1047-1051.

Norcini, J. G., J. H. Aldrich and F. G. Martin (2001): Seed source effects on growth and flowering of Coreopsis lanceolata and Salvia lyrata. Journal of Environmental Horticulture 19: 212-215. 